Nim : 90100121095

Kelas : Ekis C

\title{
KONSEP ILMU EKONOMI
}

IImu ekonomi adalah ilmu yang mengajarkan kita memanajemen dan memilih prioritas kebutuhan apa yang harus dipenuhi dikarenakan kelangkaan alat pemuas kebutuhan.

kelangkaan, adalah suatu kondisi ketika manusia memerlukan sesuatu, maka dibutuhkan usaha atau pengorbanan untuk memperolehnya, kelangkaan membahas 2 hal umum.

https://money.kompas.com/read/2021/06/23/160655626/apa-yang-dimaksud-dengan-kelangkaandalam-ekonomi. kelangkaan kebutuhan terbatas dibagi menjadi beberapa bagian:

\section{1. kebutuhan tidak terbatas}

kebutuhana manusia sifatnya tidak terbatas Maka, kebutuhan manusia dapat diartikan sebagai sesuatu yang dibutuhkan oleh manusia, atau keinginan manusia yang harus dipenuhi, demi tercapainya kepuasan rohani maupun jasmani untuk keberlangsungan hidupnya. Kebutuhan ini dapat berupa barang ataupun jasa.

intensitas, ternyata kebutuhan, ada intensitasnya. Nah, berdasar intensitas, kebutuhan juga masih diturunkan menjadi beberapa kelompok,

1. Kebutuhan primer disebut juga sebagai kebutuhan pokok, merupakan kebutuhan manusia akan hidup yang layak.

2. Kebutuhan sekunder merupakan kebutuhan yang muncul setelah kebutuhan primer terpenuhi. Setiap individu memiliki kebutuhan sekunder yang beragam, kebutuhan ini tergantung pada keinginan dan kemampuan masing-masing individu untuk memenuhi.

3. Kebutuhan tersier merupakan turunan berikutnya dari kelompok kebutuhan manusia berdasar intensitasnya. Kebutuhan tersier akan muncul jika kebutuhan primer dan sekunder telah terpenuhi.

sifat, Pengelompokan kebutuhan manusia berikutnya adalah kebutuhan manusia berdasarkan sifatnya.

1. Kebutuhan Jasmani

Pasti sudah paham ya, yang namanya jasmani, berkaitan dengan raga atau tubuh. Kebutuhan jasmani merupakan kebutuhan yang diperlukan oleh tubuh agar dapat memenuhi kepuasan raga.

\section{Kebutuhan Rohani}

Sebagai pendamping jasmani, maka ada pula kebutuhan rohani. Kebutuhan rohani merupakan kebutuhan yang diperlukan oleh batin atau jiwa, pengaruh jika kebutuhan ini dipenuhi adalah, manusia mendapat kebahagiaan. 
waktu pemenuhan, Kebutuhan berdasar waktu keperluannya disini bukan membicarakan mengenai durasi, Tetapi akan menjelaskan mengenai masa.

1. kebutuhan sekarang merupakan kebutuhan yang harus dipenuhi saat ini, tidak dapat ditunda.

2. Kebutuhan yang Akan Datang,Berdasar waktu keperluannya, jenis kebutuhan ini merupakan yang paling toleran, karena kebutuhan ini boleh dipenuhi di kemudian hari, dapat ditunda, dan sifatnya tidak mendesak.

subjek, Pada kelompok ini, kebutuhan manusia dibagi lagi menjadi dua macam,

1. 1.individu berarti merupakan kebutuhan yang diperlukan oleh setiap individu. Mengapa disebut sebagai kebutuhan individu? Karena setiap individu lahir beragam dan memiliki kebutuhan masing-masing.

2. 2.kelompok, merupakan suatu kebutuhan yang pemanfaatannya untuk kepentingan orang banyak.

sumber dibagi menjadi 2 yaitu

1. Kebutuhan Sosial

Kebutuhan sosial merupakan kebutuhan yang muncul karena kedudukan seorang individu dalam masyarakat, sehingga individu tersebut harus mampu menyelenggarakan berbagai upaya, agar dipandang kayak.

2. Kebutuhan psikologis merupakan kebutuhan yang berkaitan dengan rohani, atau kondisi batin dari seseorang.

https://www.gramedia.com/literasi/kebutuhan-manusia/\#Alat Pemuas Kebutuhan Manusia

2. alat pemuas terbatas, Banyaknya kebutuhan yang dibutuhkan manusia, seakan tidak ada habisnya. Inilah yang menjadi alasan mengapa alat pemuas kebutuhan sifatnya terbatas.

https://www.merdeka.com/jabar/penyebab-mengapa-alat-pemuas-kebutuhan-sifatnya-terbatasberikut-penjelasannya-kln.html 